\title{
Telecommunication Infrastructure Development and FDI into Asian Developing Nations
}

\author{
DR. MUMTAZ HUSSAIN SHAH \\ Assistant Professor, Institute of Management Studies \\ University of Peshawar, Pakistan \\ shah_mumtaz@hotmail.com \\ FAISAL KHAN \\ Post Graduate Research Scholar, Institute of Management Studies \\ University of Peshawar
}

\begin{abstract}
This study strives to evaluate the effects of infrastructure availability and development on foreign direct investment (FDI) in host developing nations. Employing fixed effects panel estimation technique, panel data for 23 Asian developing countries, from 1990-2009 is used with heteroscedasticity corrected standard errors. The results reveal a strong favourable impact of telecom infrastructure (measured by mobile subscriptions) in drawing inward FDI. Therefore, it is concluded that a country with improved infrastructure in general and telecom infrastructure in particular is likely to pull in more FDI. Other variables such as market size, economic development, and currency valuation (measured by exchange rate) appear important in captivating multinational investors, as they exhibit significant coefficients. On the contrary, high-inflation significantly deters inward FDI.
\end{abstract}

Keywords: FDI, Telecommunication Infrastructure, Panel Data

\section{Introduction}

Developing nations generally face capital scarcity. There domestic savings are insufficient and access to worldwide financial markets is limited or in-existent (Shah, 2016b). In such conditions, foreign direct investment (FDI) can be one of the vital sources of capital funds. FDI consist of equity funds, earnings that are reinvested and intra-company borrowings (Shah, 2018a). FDI may also be referred to as an equity capital put in foreign countries which provide the most desirable capital funds, promote production techniques, brings in superior administrative skills, provide advertising knowledge and develop worldwide links (Shah, 2011d). Moreover, some studies and analysis illustrates that FDI encourages domestic investment in emerging countries, as asserted by Bosworth, Collins and Reinhart (1999). FDI improve productivity, causes movement of modern technology and also generate employment and increase competition (Kobrin, 2005;Le \&Ataullah, 2006; Shah, 2012; Shah \& Jamil, 2016). FDI inflows in Asian economies is influenced by various structural components, for instance market dimensions, income level, human resources, level of urbanization, infrastructure, labour cost, performance requirement and other macroeconomic factors (Shah, 2017d). This 
study attempts to examine impact of telecom (mobile/cellular) infrastructure growth on FDI inflows in developing countries from Asia for the time period of 19902009. Advanced level telecom infrastructure reduces time wastage, decrease communication and information costs, hence promoting business activities (Shah, 2014b). The swift expansion of cellular sector in emerging countries has occurred mainly due to the liberalisation in telecomm sector (Shah, 2011e). Consequently, there islesser reason to presume that this sector is associated with general measures of infrastructure. Modern technological advancement in telecom sector has been and still is an imperative tool in enabling the multinationals to swiftly communicate data and information from the headquarters to the foreign affiliates or from one subsidiary to other (Shah \& Azam, 2018). Telecommunication infrastructure favourably supports domestic growth, link domestic trade markets and is also indispensable for intercontinental trade (Shah \& Qayyum, 2015). With the progression of telecom industry, an innovative market structure, widened enterprise value chains and a low-cost mechanism is possible as argued by Kambil and Short (1994).

Prior to 1990slandline facilities were available at limited-level.However, the telecom sector innovations in last decade of twentieth century revolutionised the entire mechanism of telecom industry. Due to which wireless, internet service providers and cell phone companies broadenedtheir operational setups. Thus, facilitating worldwide financial transactions, smoother multinational connectivity across nations and promoting economic growth ${ }^{1}$. Because of liberalization in telecom sector the international capital can now move smoothly in shape of $\mathrm{FDI}^{2}$. Cell phone industry boomed. Moreover, topand finest quality services at minimum tariff broadened the market causing economies of scale (Shah, 2017c). Though, various earlier studies have explored the impact of general telecom and transport infrastructure on inward FDI (see for example, Reynolds, Kenny, Liu \& Qiang, 2004;Escribano, Garrido, Peltier \& Singh, 2005;Seetanah\&Khadaroo, 2007 etc.). This study is distinct from others because it places particular emphasis on the impact of cellular (mobile) infrastructure on inbound FDI. Special attention on the role of telecom/cellular infrastructure in attracting FDI in the past literature is missing ${ }^{3}$. So, it's imperative to evaluate its role. The rest of the research paper is structured as follows: Introduction is followed by literature review and theoretical background in part two. The third part describes data and methodology. The fourth contains estimation concerns. Part five presents results and analysis. Whilst part six concludes.

\section{Literature Review}

Numerous studies have identified market size and development level to be essential FDI attracting factors for instanceNigh (1985) conducted econometric analysis on US manufacturing sector investment from 1954 to 1975, in 24 economies and observed per

1. See Zahra, Azim and Mahmood (2008).

2. General Agreement of Trade in Services (GATS) brought revolutionary reforms in telecommunications sector.

3. To the best of our knowledge, researchers have used various proxies for telecom infrastructure such as fixed landline connections etc. however this study examined influence of mobile subscriptions on FDI for the first time. 
capita GDP of host nation state as an essential FDI driving factor. Sader (1993) found a strong association between FDI and market-size by employing data of 21 emerging economies from 1988 to 1992, through cross country regression analysis. Likewise, Tsai (1994) analysed a sample of 62 nations from 1975 to 1978 and also for 51 nations from 1983 to 1986 and confirmed that a country's larger market-size is responsible forhigher FDI. Shamsuddin (1994) obtained a parallel conclusion. Chen (1996) analysed the FDI determinants regionally in China with pooled cross section data and time series analysis over the period of 1987-1991. He argued that market share development favourably affects FDI. Other studies that have identified market size and development level to be crucial FDI attracting factors, includes, for instance Nunnenkamp (1997); Resmini (2000);Chakrabarti (2001);Sun, Tong, and Yu, (2002);Fan, Morck, Xu, and Yeung (2007) andShah (2011c, 2013\& 2018d).

Kravis and Lipsey (1982);Nunes, OscáteguiArteta and Peschiera (2006);Choong and Lam (2010)and Shah (2015)provided evidence confirming importance of trade openness. Borensztein, De Gregorio and Lee (1998) pointed out the significance of human capital expansion or education level stating that qualified personnel is a decisive factor for FDI. Noorbakhsh, Paloni and Youssef (2001) found that human skills are statistically significant and the most central element for improving FDI inflows. Moreover,its worth has increased over time. Mengistu and Adhikary (2011) and Shah (2014a)research havealso highlighted the significance of human capital. Reinhart and Rogoff (2003)stressed that inflation tarnish currency'svalue, because it has negative effect on growth, and consequently adverselyaffect FDI also. De Wet (2003) proposed that lowlevel inflation together with other essentials e.g. exalted economic growth can lure international investors and boost inward FDI to Turkey. As a result, low inflation isfavouredby countries that support FDI for promoting economic growth.Nonnemberg and De Mendonça (2004);Akinboade, Siebrits and Roussot (2006) and Shah and Zeb (2017) found negative impact of inflation on foreign investors.

Frootand Stein (1991);Blonigen (1996) and Shah (2016c) observed the impact of exchange rate on FDI. According to them a decline in host currency must augment inward FDI in the host economywhereas rise in its currency drivesoutvertical export oriented FDI. Conversely, analysing multinational firms in US, Campa (1993) hypothesised that the host's currency appreciation actually promotes direct investment into the host country, implying that currency appreciation enhances the prospects of future dividend earnings in terms of home currency. Blonigen and Feenstra (1996) noticed a considerable negative association of a country's exchange rate with FDI. Aqeel and Nishat (2004) used error correction and co-integration approaches to unfold and elucidate the preferred FDI indicators in Pakistan for 1961-2003. They claimed that progressive exchange rates encourage FDI, because multinational firms identify it as a positive signal of the economy.

Root and Ahmed (1979) claim about infrastructure's importance for FDI was later on confirmed by studies likeWheeler andMody(1992); Head and Ries (1996); Kinoshita (1998); Cheng and Kwan (2000) and Shah (2017a). Asiedu (2002) claimed that physical infrastructure is appropriate only for investments based on non-extractive industries. Therefore, with time the host economies must furnish infrastructure of superior quality, 
as compared to infrastructure existing in preceding years, to facilitate new forms of FDI. Reynolds et al. (2004) found an approving influence of telephone lines in accelerating FDI. Lydonand Williams (2005) found that average FDI inflows in developing economies are better in those countries that contain advance telecommunication networks.Escribanoet al. (2005) and Castro (2007) also maintain infrastructure's importance for FDI. Kumar (2006) determined a single combined infrastructure index, which capture availability of energy, telecommunications, information and transport infrastructure for 66 economies from 1982 to 1994. The estimations confirmed that quality infrastructure availability does enhance the attractiveness of an economy formultinational investors, holding other things constant. Seetanah and Khadaroo (2007) analysed infrastructure accessibility as a component of FDI inflows in case of 25 African countries. They found that transport infrastructure availability is a favourable element for the attractiveness of economies considered. Overseas investors are also attracted by various other forms of infrastructure such as telecommunication infrastructure. However, Quazi (2005) declared insignificant impact of infrastructure on inbound FDI. MengistuandAdhikary (2011) also found that infrastructure (measured by telephone lines per 1000 populace) acts as significant FDI stimulating factor.

\section{Econometric Model and Data}

The possible econometric model is given below as equation (a):

$$
\mathrm{FDI}_{\mathrm{jt}}=f\left[\begin{array}{c}
\text { MarketSize }_{\mathrm{jt}}+\text { DevelopmentLevel }_{\mathrm{jt}}+\text { HumanCapital }_{\mathrm{jt}}+\text { Openness }_{\mathrm{jt}} \\
\text { +Economic Stability } \\
\text { Ev }_{\mathrm{t}}+\text { Currency Value }_{\mathrm{jt}}+\text { Infrastructure }_{\mathrm{jt}}+\xi_{\mathrm{jt}}
\end{array}\right]
$$

Where $\xi$ represents stochastic error term, $j$ individual countries that vary from 1 to 23 and $t$ denotethe time period that varies from 1990 to 2009. Therefore, we can have a maximum of $23 * 20=460$ observations for each variable.

Log linearizing equation (a) and putting appropriate proxies for all regressors, we get:

$$
\text { LnFDISt }_{\mathrm{jt}}=\begin{gathered}
\alpha_{0}+\beta_{1} \operatorname{LnPOP}_{\mathrm{jt}}+\beta_{2} \operatorname{LnGDPPC}_{\mathrm{jt}}+\beta_{3} \operatorname{LnLIT}_{\mathrm{jt}}+\beta_{4} \operatorname{LnTRD}_{\mathrm{jt}} \\
+\beta_{5} \operatorname{LnINF}_{\mathrm{jt}}+\beta_{6} \operatorname{LnEXR}_{\mathrm{jt}}+\beta_{7} \operatorname{LnTEL}_{\mathrm{jt}}+\xi_{\mathrm{jt}}
\end{gathered}
$$

Where Ln denotes natural logarithms, LnFDIST is FDI stock measured in US dollars; POP is population used as measure of market size, GDPPC indicates per capita GDP, incorporated for development level and TRD is trade, used for openness. LIT represents literacy rate, used for human capital, INF is inflation, used to capture macroeconomic stability and EXR indicates exchange rate, used for currency valuation. TEL is telecom infrastructure included in themodel to examine infrastructure effects. Data regarding FDI, exchange rate and inflation is extracted from UNCTAD, PWT 7.0 and IMF-IFS ${ }^{4}$ respectively. The data on population, trade, GDP per capita and infrastructure is from World Bank,World Development Indicators ${ }^{5}$, whereas, data regarding literacy is obtained from Barro and Lee(2013) education attainment dataset.

4.wWw.imf.com

5.www.worldbank.org

Shah \& Khan 


\subsection{Estimation Concerns}

The summary of all the descriptive statistics for the variables used in the analysis are given as table 1

Table 1: Descriptive Statistics

\begin{tabular}{|c|c|c|c|c|c|c|}
\hline Variables & $\begin{array}{c}\text { Number of } \\
\text { observation }\end{array}$ & Mean & Median & Variance & Minimum & Maximum \\
\hline LnFDIST & 460 & 21.9575 & 22.2779 & 8.5115 & 11.8495 & 26.9198 \\
\hline LnPOP & 460 & 17.3272 & 17.0875 & 3.1934 & 13.1081 & 21.0095 \\
\hline LnGDPPC & 460 & 6.9677 & 6.8955 & 1.1815 & 4.5954 & 9.9434 \\
\hline LnLIT & 460 & 4.3428 & 4.4841 & 0.1110 & 2.7850 & 4.6086 \\
\hline LnINF & 460 & 2.2283 & 2.1890 & 1.7767 & -3.0576 & 7.8639 \\
\hline LnEXR & 460 & 3.8917 & 3.7478 & 7.0517 & 0.0007 & 9.7949 \\
\hline LnTEL & 460 & 11.6708 & 13.0466 & 30.9265 & 0.0000 & 20.4319 \\
\hline
\end{tabular}

Values are rounded off to four decimal places.

Hausman(1978) specification test statistic of 45.69 showed a significant difference, as pvalue was less than $1 \%$ and hence $\mathrm{H}_{0}$ is rejected in favour of $\mathrm{H}_{1}$, implying that only fixed effect estimator is appropriate (Shah\& Khan, 2018).Breush-Pagan/Cook-Weisberg test revealed the presence of heteroscedasticity (Shah, 2017b). Thus, robust standard errors are reported in all the estimations (Shah \& Afridi, 2015).Initially,Variance Inflation Factor (VIF) test revealed that multicollinearity is severe (Shah \& Khan, 2017). When the trade (openness) variable was dropped the corresponding mean value of VIF reduced to $3.76 \%$, signallingthat multicollinearity is no more a problem (Shah, 2009\& Shah, 2018c). Therefore, trade was not incorporated in the final model.

Table 2reports the correlation matrix showing thatLnFDIST has positive correlation with variables LnPOP, LnGDPPC, LnTRD, LnLIT, LnEXR, and LnTEL whereas it has a weak negative correlation with LnINF and LnEXR. Excessive correlation among the explanatory variables also signals the existence of problematic multicollinearity (Shah \&Gulelala, 2017).

Table 2: Correlation Matrix

\begin{tabular}{ccccccccc}
\hline Variables & LnFDIST & LnPOP & LnGDPPC & LnTRD & LnLIT & LnINF & LnEXR & LnTEL \\
\hline LnFDIST & 1.000 & & & & & & & \\
LnPOP & 0.553 & 1.000 & & & & & & \\
LnGDPPC & 0.567 & -0.184 & 1.000 & & & & & \\
LnTRD & 0.912 & 0.697 & 0.540 & 1.000 & & & & \\
LnLIT & 0.228 & -0.183 & 0.353 & 0.186 & 1.000 & & & \\
LnINF & -0.309 & -0.004 & -0.219 & -0.198 & -0.034 & 1.000 & & \\
LnEXR & -0.009 & 0.197 & -0.376 & -0.059 & 0.016 & 0.000 & 1.000 & \\
LnTEL & 0.751 & 0.325 & 0.451 & 0.647 & 0.255 & -0.338 & 0.081 & 1.000 \\
\hline
\end{tabular}

\section{Results And Analysis}

Values are rounded off to four decimal places.

Model1 in table 3 exhibits that population (LnPOP) and literacy rate (LnLIT) is not significant. The coefficient of GDP per capita (LnGDPPC) is 1.293 and is strongly significant, which implies that if LnGDPPC increases by 1, it would positively affect 
FDI. So, the result shows that higher development level attracts FDI. This outcome supports evidence presented by Lunn (1980);Nigh (1985); Resmini (2000); Shah (2011b) and Shah and Faiz (2015), who observed favourable growth effects. Thus, a rapid economic growth presents certain better prospects for profit making and greatly pulls in foreign investments (Shah, 2018b). On the basis of this (development) rationale, it can be said that investors tend to put capital in an economy with better growth prospects (Shah, 2010). Thereby, demonstrating that the recipient country growth outlook affect inward FDI. In the $2^{\text {nd }}$ model inflation rate (LnINF) as anticipated is statistically significant at $1 \%$ level with a negative sign. The coefficient of LnINF is -0.292 , indicating that if inflation increases, FDI inflow would be negatively affected. This outcome confirms Nonnemberg et al, (2004); Shah (2011a) and Shah and Ali (2016) finding's that highinflation reduce FDI inflows. Considering the significant negative impact of inflation on FDI, it is evident that high-level inflation hinders inward FDI.

In the $3^{\text {rd }}$ model the findings reveal that LnEXR (exchange rate) is statistically significant at $1 \%$. Its coefficient (0.499) implies that if exchange rate decreases by 1 , it will increase FDI inflows. Similar findings were reported by Shah (2016a). Model4 illustrates the significance of LnTEL, being significant at $1 \%$, with a positive coefficientproves that telecom infrastructure favourably effect FDI. This result is consistent with Reynolds et al, (2004);Lydonand Williams (2005) and Shah and Samdani (2015) finding's regarding infrastructure availability. We can say that the presence of communication infrastructure in emerging countries is linked with high-levels of inward FDI. It, therefore,seems appropriate to argue that in addition to growth level and exchange rate, the availability and quality of telecom infrastructure also helps in improving overall investment ambiance in the host country and facilitates FDI inflow. These findings recommend that the availability and quality of telecom infrastructure is an essential ingredient of the recipe to attract inbound FDI.

Table 3:Estimation Results with Fixed Effects

\begin{tabular}{|c|c|c|c|c|c|}
\hline Variables & Proxy & 1 & 2 & 3 & 4 \\
\hline Market Size & LnPOP & $\begin{array}{c}2.8426 \\
(2.7002)\end{array}$ & $\begin{array}{c}3.1185^{* * *} \\
(0.9472)\end{array}$ & $\begin{array}{c}2.8923 * * * \\
(0.8081)\end{array}$ & $\begin{array}{l}1.5818 * * \\
(0.7631)\end{array}$ \\
\hline Development Level & LnGDPPC & $\begin{array}{c}1.2917 * * * \\
(0.3861)\end{array}$ & $\begin{array}{l}1.1090 * * * \\
(0.1236)\end{array}$ & $\begin{array}{c}1.1092 * * * \\
(0.1182)\end{array}$ & $\begin{array}{c}0.8122 * * * \\
(0.1260)\end{array}$ \\
\hline Human Capital & LnLIT & $\begin{array}{c}0.3414 \\
(2.0234)\end{array}$ & $\begin{array}{l}-0.4871 \\
(1.3832)\end{array}$ & $\begin{array}{l}-1.8196 \\
(1.4346)\end{array}$ & $\begin{array}{l}-2.0101 * \\
(0.9856)\end{array}$ \\
\hline Economic Stability & LnINF & & $\begin{array}{c}-0.2922 * * * \\
(0.0862)\end{array}$ & $\begin{array}{c}-0.1778 * * * \\
(0.0526)\end{array}$ & $\begin{array}{c}-0.1331 * * \\
(0.0480)\end{array}$ \\
\hline Currency Value & LnEXR & & & $\begin{array}{c}0.4986 * * * \\
(0.1514)\end{array}$ & $\begin{array}{l}0.2643^{*} \\
(0.1535)\end{array}$ \\
\hline Infrastructure & LnTEL & & & & $\begin{array}{c}0.0970 * * * \\
(0.0247)\end{array}$ \\
\hline \multirow{2}{*}{\multicolumn{2}{|c|}{$\begin{array}{c}\text { No. of Observations } \\
\text { R-Squared }\end{array}$}} & 460 & 460 & 460 & 460 \\
\hline & & 0.3263 & 0.4794 & 0.3947 & 0.4967 \\
\hline
\end{tabular}




\section{Conclusion}

Foreign direct investment bridges the gap of regional savings and capital investment, improves technological expertise, thus providing assistance in industrial and economic progress in emerging economies (Shah \& Khan, 2016). Though, most developing economies have been modifying their policy objectives and strategies to pull in FDI, only a few Asian countries with sizable market shave succeeded so far. The inflow of capital into developing countries is because of a diverse set of location pull factors; however, this paper tried to shed light on the scope of telecom infrastructure development in effecting inward FDI. This research study provides understanding regarding FDI and mobile cellular infrastructure for assisting investors and policy makers in investment decision making regarding the host choice in Asian region. The findings also show that the level of development measured by per-capita GDP in previous years, being strongly significant, positively influences inbound FDI. Inflation reflecting macroeconomic instability with a strong negative coefficient exhibits negative effects on inward FDI. A country's exchange rate also proved to have an important positive effect, exerting that slow and gradual currency depreciation increases FDI. The benefits of inbound FDI are indispensable and if a country wishes to attain benefits of international investment, it must constantly regulate its economic policies and improve infrastructure facilities to suit the requirements of transnational investors. Thus, we can conclude that the presence of telecommunication infrastructure in developing countries is linked with high-level of inward FDI.

\section{References}

Asiedu, E. (2002). On the determinants of foreign direct investment to developing countries: Is Africa different?. World Development, 30(1), 107-119.

Akinboade, O.A., Siebrits, F.K., \& Roussot, E.N. (2006). Foreign direct investment in South Africa.

Aqeel, A., \& Nishat, M. (2004). The determinants of foreign direct investment in Pakistan. Pakistan Development Review, 43(4 Part II), 651-664.

Barro, R.J., \& Lee, J.W. (2013). A new data set of educational attainment in the world, 1950-2010. Journal of Development Economics, 104, 184-198.

Blonigen, B.A., \& Feenstra, R.C. (1996). Effects of US trade protection and promotion policies. NBER Working Paper, 5285.

Blonigen, B.A. (1996). Explaining Japanese foreign direct investment in the United States, Unpublished PhD Dissertation, University of California, Davis.

Borensztein, E., De Gregorio, J., \& Lee, J.W. (1998). How does foreign direct investment affect economic growth? Journal of International Economics, 45(1), 115-135.

Bosworth, B.P., Collins, S.M., \& Reinhart, C.M. (1999). Capital flows to developing economies: Implications for saving and investment. Brookings Papers on Economic Activity, 1999(1), 143-180.

Campa, J.M. (1993). Entry by foreign firms in the United States under exchange rate uncertainty. Review of Economics \& Statistics, 75(4), 614-622. 
Castro, L. (2007). Infrastructure and the location of foreign direct investment: A regional analysis. University Library of Munich, Germany.

Chakrabarti, A. (2001). The determinants of foreign direct investments: Sensitivity analyses of cross country regressions. Kyklos, 54(1), 89-114.

Chen, C.H. (1996). Regional determinants of foreign direct investment in mainland China. Journal of Economic Studies, 23(2), 18-30.

Cheng, L.K., \& Kwan, Y.K. (2000). What are the determinants of the location of foreign direct investment? The Chinese experience. Journal of International Economics, 51(2), 379-400.

Choong, C. K., \& Lam, S.Y. (2010). The determinants of foreign direct investment in Malaysia: A revisit. Global Economic Review, 39(2), 175-195.

De Wet, W.A. (2003). Thinking like a governor: Central banking under an inflation target. South African Journal of Economics, 71(4), 792-805.

Escribano, A., Garrido, L., Peltier, N., \& Singh, H. (2005). The Impact of infrastructure on competitiveness: A firm level analysis based on ICA surveys. Joint Conference of the Inter-American Development Bank (IADB) and the World Bank.

Fan, J. P., Morck, R., Xu, L.C., \& Yeung, B. (2007). Does good government draw foreign capital? Explaining China's exceptional foreign direct investment inflow (No. 4206). The World Bank.

Froot, K. A., \& Stein, J. C. (1991). Exchange rates and foreign direct investment: An imperfect capital markets approach. The Quarterly Journal of Economics, 106(4), 11911217.

Hausman, J. (1978). Specification tests in econometrics. Econometrica, 46(6), 12511271.

Head, K., \& Ries, J. (1996). Inter-city competition for foreign investment: Static and dynamic effects of China's incentive areas. Journal of Urban Economics, 40(1), 38-60.

Kambil, A., \& Short, J.E. (1994). Electronic integration and business network redesign: A roles-linkage perspective. Journal of Management Information Systems, 10(4), 59-83.

Kinoshita, Y. (1998). Micro-determinants of Japanese foreign direct investment in Asia. Eastern Economic Association and Japan Economic Seminar at Columbia University.

Kobrin, S.J. (2005). The determinants of liberalization of FDI policy in developing countries: A cross-sectional analysis, 1992-2001. Transnational Corporations, 14(1), 67104.

Kravis, I. B., \& Lipsey, R.E. (1982). The location of overseas production and production for export by US multinational firms. Journal of International Economics, 12(3-4), 201223.

Kumar, N. (2006). Infrastructure availability, foreign direct investment inflows and their export orientation: A cross-country exploration. The Indian Economic Journal, 54(1), 125-144.

Le, M. H. \& Ataullah, A. (2002). Foreign capital and economic performance of Pakistan. Lahore Journal of Economics, 7(1), 1-32.

Lunn, J. (1980). Determinants of US direct investment in the EEC: Further evidence. European Economic Review, 13(1), 93-101. 
Lydon, R. \& Williams, M. (2005). Communications networks and foreign direct investment in developing countries (No. 2492). University Library of Munich, Germany. Mengistu, A. A., \& Adhikary, B.K. (2011). Does good governance matter for FDI inflows? Evidence from Asian economies. Asia Pacific Business Review, 17(3), 281-299. Nigh, D. (1985). The effect of political events on United States direct foreign investment: A pooled time-series cross sectional analysis. Journal of International Business Studies, 16(1), 1-17.

Nonnemberg, M. B. \& De Mendonça, M. J. C. (2004). The determinants of foreign direct investment in developing countries. Anais do XXXII Encontro Nacional de Economia (No. 061). ANPEC-Associação Nacional dos Centros de Pósgraduação em Economia.

Noorbakhsh, F., Paloni, A., \& Youssef, A. (2001). Human capital and FDI inflows to developing countries: New empirical evidence. World Development, 29(9), 1593-1610.

Nunes, L. C., Oscátegui A. J. A., \& Peschiera, J. (2006). Determinants of FDI in Latin America. Documento De Trabajo 252.

Nunnenkamp, P. (1997). Foreign direct investment in Latin America in the era of globalized production. Transnational Corporations, 6, 51-82.

Quazi, R. (2007). Economic freedom and foreign direct investment in East Asia. Journal of the Asia Pacific Economy, 12(3), 329-344.

Resmini, L. (2000). The determinants of foreign direct investment in the CEECs: New evidence from sectoral patterns. Economics of Transition, 8(3), 665-689.

Reynolds, T., Kenny, C., Liu, J., \& Qiang, C. Z. W. (2004). Networking for foreign direct investment: The telecommunications industry and its effect on investment. Information Economics and Policy, 16(2), 159-164.

Reinhart, C., \& Rogoff, K. (2003). FDI to Africa: The role of price stability and currency instability. IMF Working Paper, 3(10).

Root, F. R., \& Ahmed, A.A. (1979). Empirical determinants of manufacturing direct foreign investment in developing countries. Economic Development and Cultural Change, 27(4), 751-767.

Sader, F. (1993). Privatization and foreign investment in the developing world. World Bank Working Paper, 1202.

Seetanah, B., \& Khadaroo, A.J. (2007). Foreign direct investment and growth: New evidences from Sub-Saharan African countries. University of Mauritius, 27.

Shah, M. H. (2009). FDI induced growth in developing countries: Does human capital matter? PhD Conference. 5 \& 11 March, 2009. University of Leicester School of Business (USLB), Leicester, UK.

Shah, M. H. (2010). Bilateral linkages with OECD and FDI inflows in leading developing countries. The $5^{\text {th }}$ International Conference on Interdisciplinary Social Sciences. 2-5, August, 2010. University of Cambridge, UK.

Shah, M. H. (2011a). Essays on foreign direct investment in developing countries (Doctoral dissertation, University of Leicester School of Business (USLB).

Shah, M. H. (2011b). The effect of associations with OECD economies on FDI inflows in leading/emerging developing countries. $4^{\text {th }}$ Italian Doctoral Workshop in Economics and Policy Analysis. 7-8 July, 2011. University of Torino and Collegio Carlo Alberto, Torino, Italy. 
Shah, M. H. (2011c). Networking with OECD economies, enhancing inward FDI in emerging developing countries. $7^{\text {th }}$ UK Social Networks Conference. 7-9 July, 2011. University of Greenwich, London, UK.

Shah, M. H. (2011d). World Trade Organisation and inward foreign direct investment in developing countries: Is it TRIMS, TRIPS or Liberalisation? $6^{\text {th }}$ International Conference on Interdisciplinary Social Sciences. 11-13, July, 2011. University of New Orleans, LA, USA.

Shah, M. H. (2011e). The significance of infrastructure for inward FDI in developing countries. International Conference on Applied Business \& Economics, ICABE, 2011. 29 Sept to 1 Oct, 2011. University of Applied Sciences, Athens, Greece.

Shah, M. H. (2012). The importance of adherence to intellectual property rights (IPRs) treaties / conventions for FDI inflows in emerging economies: Evidence from OECD outward FDI. International Network for Economic Research, $14^{\text {th }}$ INFER Annual Conference. 10-13 May, 2012. Faculty of Economics, University of Coimbra, Portugal.

Shah, M. H. (2013). The effect of macroeconomic stability on inward FDI in developing countries. European Economics and Finance Society, $12^{\text {th }}$ Annual EEFS Conference. 2023 June, 2013. Westin Grand, Berlin, Germany.

Shah, M. H. (2014a). The role of human capital in the host economy on inward FDI in developing countries. West East Institute, European Academic Conference Budapest, 2225 June, 2014. Mercure Budapest Korona, Hungary.

Shah, M. H. (2014b). The significance of infrastructure for FDI inflow in developing countries. Journal of Life Economics, 2, 1-16.

Shah, M. H. (2015). Impact of trade liberalization on FDI inflows in emerging countries. International Social Sciences and Education Research Conference ICBTS2015, 9-13 June, 2015. Harvard University, Boston, Massachusetts, USA.

Shah, M.H., \& Afridi, A.G. (2015). Significance of good governance for FDI inflows in SAARC countries. Business \& Economic Review. 7(2), 31-52.

Shah, M. H., \& Faiz, M. (2015). Terrorism and foreign direct investment: An empirical analysis of SAARC countries. City University Research Journal, 5(2), 219-233.

Shah, M.H., \& Qayyum, S. (2015). Impact of double taxation treaties on inward FDI in Latin American and Caribbean developing countries. Business \& Economic Review. 7(1), $1-18$.

Shah, M. H., \& Samdani, S. (2015). Impact of trade liberalization on FDI inflows to D-8 countries. Global Management Journal for Academic \& Corporate Studies, 5(1), 30-37.

Shah, M. H. (2016a). The effect of intellectual property rights on foreign direct investment in East Asia and Pacific developing countries. European Economics and Finance Society, $15^{\text {th }}$ Annual EEFS Conference. 16-19 June, 2016. Crown Plaza Hotel, Amsterdam, Netherland.

Shah, M.H. (2016b). Financial development and foreign direct investment: The case of Middle East and North African (MENA) developing nations. University of Haripur Journal of Management, 1(2), 93-109.

Shah, M. H. (2016c). The effect of macroeconomic stability on inward FDI in African developing countries. International Journal of Business Studies Review. 1(1), 1-9. 
Shah, M. H., \& Ali, Z. (2016). What drives foreign direct investment to BRICS? PUTAJ Humanities and Social Sciences, 23(1), 51-66.

Shah, M. H., \& Jamil, I. (2016). Trade agreements and transnational corporations presence in the developing Asia. International Journal of Business Studies Review. 1(1), $56-65$.

Shah, M. H., \& Khan, Y. (2016). Trade liberalization and FDI inflows in emerging economies. Business \& Economic Review, 8(1), 35-52.

Shah, M. H., (2017a). Significance of WTO's trade related investment measures (TRIMs) agreement for inward FDI in Sub-Saharan Africa. City University Research Journal, 7(1), 17-29.

Shah, M. H., (2017b). Political institutions and the incidence of FDI in South Asia. Business \& Economic Review, 9(1), 21-42.

Shah, M. H., (2017c). Inward FDI in East Asian \& Pacific developing countries due to WTO led liberalisation. Business \& Economic Review, 9(2), 1-20.

Shah, M. H., (2017d). Economic institutions \& FDI in South Asia. $6^{\text {th }}$ International Institute of Social \& Economic Sciences, Business \& Management Conference, 27-30 June, 2017. Novotel, Geneva, Switzerland.

Shah, M. H., \& Gulelala. (2017). Autocracy, democracy and FDI inflows in Asian developing countries. International Journal of Business Studies Review. 2(1), 66-77.

Shah, M. H., \& Khan, A. U. (2017). Factors determining capital structure of Pakistani non-financial firms. International Journal of Business Studies Review. 2(1), 41-52.

Shah, M.H., \& Khan, S. (2017). Factors effecting commercial banks profitability in Pakistan. Journal of Business and Tourism. 3(1), 1-12.

Shah, M.H., \& Zeb, A. (2017). Prudent macro management of the economy and inward FDI in ASEAN member states. International Journal of Business Studies Review. 2(2), 66-85.

Shah, M. H. (2018a). Foreign direct investment and trade related intellectual property rights (TRIPS): The case of Latin American \& Caribbean developing economies. NICE Research Journal of Social Science. 11(1), 1-17.

Shah, M. H. (2018b). Corruption and foreign direct investment: The case of South Asia? PUTAJ Humanities and Social Sciences, 25(1), 1-16.

Shah, M. H. (2018c). Bilateral investment treaties and multinational investors: Evidence from FDI in MENA States. University of Central Punjab (UCP) Paradigms, 12(1), 94102.

Shah, M. H., \& Azam, A. (2018). Financial development and investors location choice in the Arab World. International Journal of Business Studies Review. 2(2), 58-74.

Shah, M. H., \& Khan, F. (2018). Profitability and working capital management nexus: Evidence from Food \& Personal Care Product Sector firms listed on Pakistan Stock Exchange. Journal of Business and Tourism. 4(1), 55-67.

Shah, M. H., (2019). The puzzle of foreign direct investment in North Africa. Workshop on the Political Economy of the Contemporary Middle East, Working Group I. 24-25 February, 2019. Center for International and Regional Studies, George Town University, Doha, Qatar. 
Shamsuddin, A. R. M. (1994). Economic determinants of foreign direct investment in less developed countries. Pakistan Development Review, 33(1), 41-51.

Sun, Q., Tong, W., \& Yu, Q. (2002). Determinants of foreign direct investment across China. Journal of International Money and Finance, 21(1), 79-113.

Tsai, P.L. (1994). Determinants of foreign direct investment and its impact on economic growth. Journal of Economic Development, 19(1), 137-163.

Wheeler, D., \& Mody, A. (1992). International investment location decisions: The case of US firms. Journal of International Economics, 33(1-2), 57-76.

Zahra, K., Azim, P., \& Mahmood, A. (2008). Telecommunication infrastructure development and economic growth: A panel data approach. Pakistan Development Review, 47(4), 711-726.

Annexures

Appendix 1: List of Countries

\begin{tabular}{|c|c|c|c|}
\hline Bahrain & Iran & Nepal & Tajikistan \\
\hline Bangladesh & Jordan & Pakistan & Thailand \\
\hline Cambodia & Kazakhstan & Philippines & Turkey \\
\hline China & Kyrgyz Republic & Sri Lanka & Vietnam \\
\hline India & Malaysia & Syrian Arab Republic & Yemen Republic \\
\hline Indonesia & Mongolia & Sri Lanka & \\
\hline
\end{tabular}

